\title{
Rancang Bangun Aplikasi Pembelajaran Bahasa Inggris Pada Platform Android (Studi Kasus : Sekolah Menangah Atas)
}

\author{
Nazruddin Safaat Harahap ${ }^{1}$, Fatima Akmal Putri ${ }^{2}$ \\ ${ }^{1,2}$ Teknik Informatika UIN Sultan Syarif Kasim Riau \\ Jl. H.R. Soebrantas no. 155 KM. 18 Simpang Baru, Pekanbaru 28293 \\ nazruddin.safaat@uin-suska.ac.id ${ }^{1}$, putrie2603@gmail.com ${ }^{2}$
}

\begin{abstract}
Abstrak - Bahasa Inggris bukanlah bahasa resmi di Indonesia. Banyak masyarakat Indonesia yang kurang mampu dalam berbahasa Inggris. Akibatnya sulit bagi masyarakat Indonesia untuk ikut dalam dunia kerja internasional. Selain itu, kurangnya praktek juga menyebabkan pembelajaran bahasa Inggris kurang menarik bagi sebagian orang khususnya pelajar. Dengan adanya praktek, kemampuan berbahasa Inggris seseorang akan terasah sehingga akhirnya terbiasa dan terlatih dalam berbahasa Inggris. Salah satu cara cerdas untuk mengatasi akan masalah tersebut adalah penggunaan aplikasi pembelajaran bahasa Inggris yang dapat diakses melalui perangkat mobile. Pada penelitian ini akan dibangun sebuah aplikasi pembelajaran bahasa Inggris yang dapat dijalankan di sistem operasi Android. Materimateri yang ditampilkan pada aplikasi ini adalah tenses, listening, speaking, idiom, expression, regular dan irregular verb, dan slang. Aplikasi ini dirancang dengan pemodelan UML, dikembangkan meng-gunakan bahasa pemrograman Java dan diujikan dengan metode blackbox dan kuesioner. Dari hasil pengujian yang dilakukan maka dapat disimpulkan bahwa sistem dapat dijalankan dengan baik dan berfungsi sesuai yang diharapkan dan nilai responden terhadap aplikasi ini sangat baik. Untuk pengembangan lebih lanjut diharapkan aplikasi ini dapat diakses pada multiplatform.
\end{abstract}

Kata kunci - Android, Mobile Learning, Mobile English Learning

\section{PENDAHULUAN}

Indonesia tidak menggunakan bahasa Inggris sebagai bahasa ibu, oleh karena itu banyak masyarakat Indonesia yang tidak lancar berbahasa Inggris. Hal ini menjadi penyebab terhambatnya mereka un-tuk ikut campur dalam dunia kerja karena hampir semua instansi mem-berikan syarat bukti bagi pelamar kerja bahwa mereka mampu berbahasa Inggris.
Selain itu yang menjadi penyebab kurangnya motivasi seseorang untuk belajar bahasa Inggris khususnya pelajar yaitu karena terlalu banyak teori dibandingkan praktek yang diberikan ketika belajar bahasa Inggris. Untuk mempelajari suatu hal yang tidak biasa dalam kehidupan sehari-hari, praktek adalah cara ampuh untuk membawa mereka terbiasa akan hal tersebut.

Dari penjelasan masalah tersebut, maka perlu diwujudkan suatu solusi agar seseorang tertarik bahkan memiliki hasrat untuk belajar bahasa Inggris. Salah satu solusi yang menarik untuk diterapkan adalah mobile learning. Dengan menggunakan mobile learning akan mempermudah pengguna dalam mempelajari sesuatu, hal ini dikarenakan pengguna dapat mengakses materi melalui smartphone. Pengguna dapat belajar dan menguji kemampuan melalui aplikasi mobile learning dimanapun dan kapanpun.

Penelitian ini membahas tentang bagaimana merancang dan membangun sebuah aplikasi pembelajaran bahasa Inggris. Aplikasi yang dibangun dapat dijalankan pada platform Android. Dengan adanya aplikasi ini pengguna dapat terbantu dalam pemahaman dan kelancaran berbahasa Inggris.

\section{LANDASAN TEORI}

\section{A. E-Learning(Electronic Learning)}

Menurut Darin E. Hartley:

e-Learning merupakan suatu jenis belajar mengajar yang memungkinkan tersampaikannya bahan ajar ke siswa dengan menggunakan media internet, intranet atau media jaringan komputer lain[16].

\section{B. M-Learning}

Clark Quinn, berdasarkan riset The eLearning Guild's 2007 Mobile Learning 360 Research Report mendefinisikan mobile learning sebagai: segala aktifitas yang memungkinkan individu untuk menjadi lebih produktif dengan cara memperoleh atau memberi suatu informasi melalui media perangkat bergerak yang dapat dibawa kemanapun[10]. 


\section{Android}

Android adalah sebuah sistem sistem operasi untuk perangkat mobile berbasis linux yang meliputi sistem operasi, middleware, dan aplikasi yang dirilis oleh Google. Android menyediakan platform terbuka bagi para pengembang untuk menciptakan aplikasi mereka [11].

\section{SDLC (System Development Life Cycle)}

Model sistem yang dikembangkan dalam menganalisa perangkat lunak menggunakan metode konvensional dengan memanfaatkan model Siklus Hidup Pengembangan Sistem (System Development Life Cycle) atau yang lebih sering disebut Waterfall Model. Waterfall adalah sebuah model perkembangan perangkat lunak dilakukan secara sekuensial, dimana satu tahap dilakukan setelah tahap sebelumnya selesai dilaksanakan.

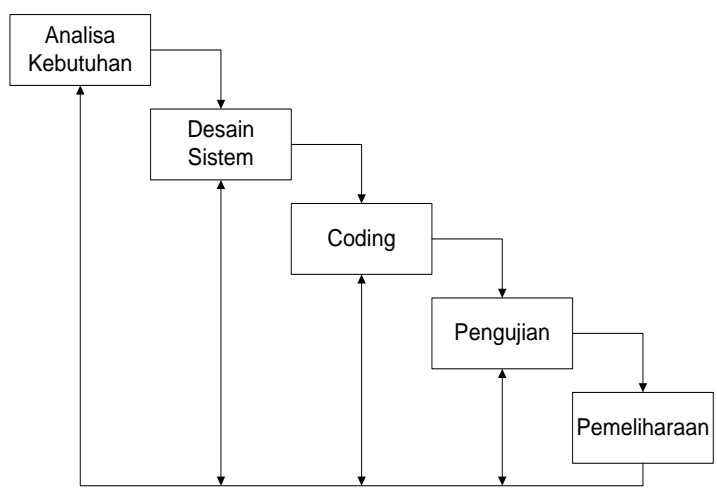

Gambar 1. Tahapan Metode Waterfall [17]

E. Analisa dan Perancangan Berorientasi Objek

Teknologi objek menganalogikan sistem aplikasi seperti kehidupan nyata yang didominasi oleh objek. Didalam membangun sistem berorientasi objek akan menjadi lebih baik apabila langkah awalnya didahului dengan proses analisis dan perancangan yang berorientasi objek. Tujuannya adalah untuk mempermudah programmer dalam mendesain program dalam bentuk objek-objek dan hubungan antar objek tersebut untuk kemudian dimodelkan dalam sistem nyata [4].

\section{ANALISA DAN PERANCANGAN}

\section{A. Deskripsi Umum Sistem}

Aplikasi yang akan diwujudkan dalam penelitian ini adalah aplikasi pembelajaran bahasa Inggris pada platform Android, yaitu aplikasi mobile yang menyediakan materi pembelajaran dan soal latihan berdasarkan materi-materi yang telah disediakan. Dengan adanya aplikasi ini pengguna dapat melatih kecakapan dan pendengaran mereka ketika berbicara dalam bahasa Inggris. Aplikasi ini ditujukan khusus untuk masyarakat Indonesia, oleh karena itu disediakan penjelasan dan terjemahan dalam bahasa Indonesia.

Course yang ditampilkan pada aplikasi ini adalah tenses, listening, speaking, expression, idiom, kamus regular dan irregular verb juga dilengkapi dengan kumpulan kalimat-kalimat infomal yang biasa diucapkan orang Amerika dalam kehidupan sehari-hari. Pada setiap course diberikan soal latihan untuk menguji pemahaman pengguna setelah mempelajari materinya. Untuk menguji pemahaman pengguna secara keseluruh-an juga disediakan soal ujian secara acak. Setelah menjawab soal sistem akan menampilkan benar atau salah jawaban yang diberikan.

\section{B. Identifikasi Kebutuhan Sistem}

Kebutuhan sistem yang akan dibangun yaitu kebutuhan sistem dari perangkat Android. Kebutuhan sistem pada perangkat Android adalah:

1. Bahasa pemrograman yang digunakan adalah Java

2. Setelah membuka aplikasi peng-guna dapat memilih menu yaitu Learn, Practice dan Random Test

3. Menu Learn, terdiri dari sub menu yaitu Tenses, Listening, Speaking, Expression, Regular And Irregular Verb, Idiom dan Slang. Masingmasing sub menu diberikan materi berikut:

a. Tenses, sistem akan menampilkan rumusrumus 16 Tenses beserta contohnya

b. Listening, pengguna dapat mendownload audio untuk didengarkan dengan seksama dan menjawab soal dengan benar.

c. Speaking, menu ini memanfaatkan teknologi Text To Speech yang mampu mengubah teks mejadi ucapan.

d. Expression, menampilkan kumpulan kalimat ekpresi dalam bahasa Inggris

e. Regular And Irregular Verb, menampilkan kamus kata kerja beraturan dan tidak beraturan

f. Idiom, menampilkan kamus idiom dalam bahasa Inggris beserta contoh

g. Slang, menampilkan kamus idiom dalam bahasa Inggris beserta contoh.

4. Menu Practice terdiri dari sub menu yaitu Tenses, Listening, Speaking, Expression, Regular And Irregular Verb, dan Idiom. Masing-masing sub menu menampilkan 20 soal yang akan dijawab oleh pengguna. Setelah pengguna selesai menjawab soal, maka sistem akan menampilkan skor yang dihitung berdasarkan jumlah poin soal yang benar yaitu 5 poin. Berikut penjelasan dari soal yang ditampilkan:

a. Tenses, pengguna harus menjawab soal objektif tentang penggunaan tenses 
b. Listening, pengguna harus memahami teks percakapan bahasa Inggris dan menjawab soal yang benar

c. Speaking, menggunakan teknologi Google Voice Search sebagai ujian pengucapan kata dalam bahasa Inggris.

d. Expression, pengguna harus menjawab soal objektif ten-tang penggunaan expression

e. Regular And Irregular Verb, sistem memberikan soal berupa sebuah kata kerja pertama lalu pengguna harus menjawab apa kata kerja kedua dan ketiga dari kata kerja pertama tersebut

f. Idiom, pengguna harus menjawab soal objektif tentang penggunaan idiom

5. Random Test, yaitu kumpulan tes secara acak berdasarkan materi yang telah diberikan. Soal Random Test akan dikelom-pokkan menurut tingkat kesulit-annya yaitu level Low, Medium dan High.

6. Update, fitur update ditampilkan di setiap sub menu berupa tombol kecil yang berfungsi untuk memperbaharui database yang ada di dalam sistem. Fitur update meliputi update Learn, Practice dan Random Test

\section{UML}

Analisa perancangan pada sistem ini menggunakan UML, yaitu terdiri dari usecase diagram, class diagram, activity diagram dan sequence diagram.

\section{Usecase Diagram}

Usecase diagram merupakan suatu aktivitas yang menggambarkan urutan interaksi antar satu atau lebih aktor dan sistem.

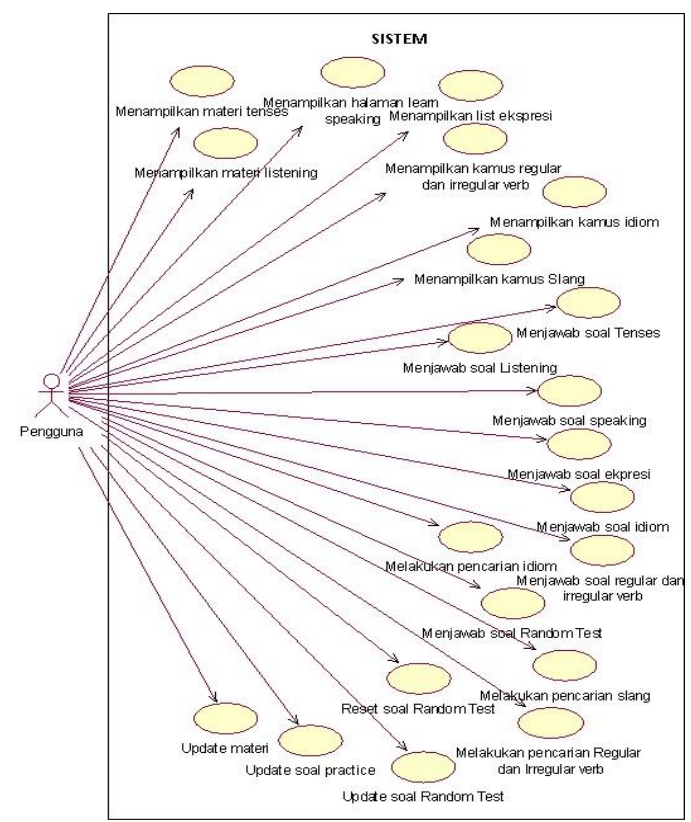

Gambar 3. Usecase Diagram

\section{Activity Diagram}

Activity diagram merupakan alur kerja pada setiap usecase. Activity diagram pada analisa ini mencakup activity diagram setiap usecase. Gambar 3 menjelaskan activity menjawab soal latihan Listening.

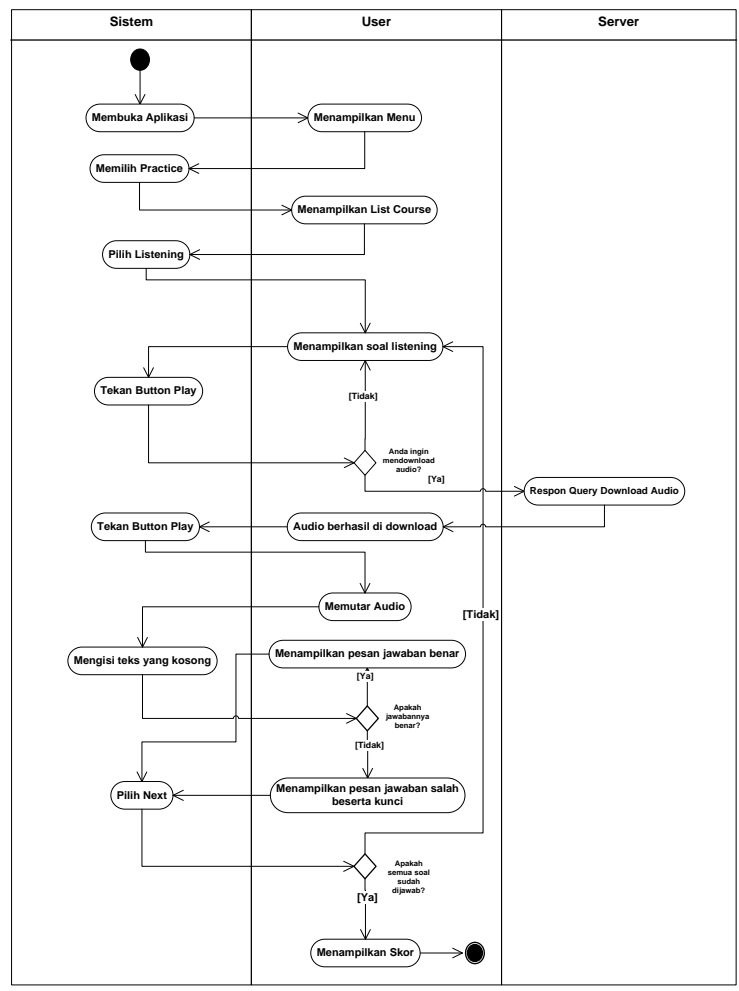

Gambar 4. Activity Diagram

\section{Sequence Diagram}

Sequence Diagram menggambarkan interaksi antar objek di dalam dan di sekitar sistem (termasuk pengguna, display dan sebagainya) berupa pesan yang digambarkan terhadap waktu. Gambar 4 menggambarkan sequence diagram menu Random Test.

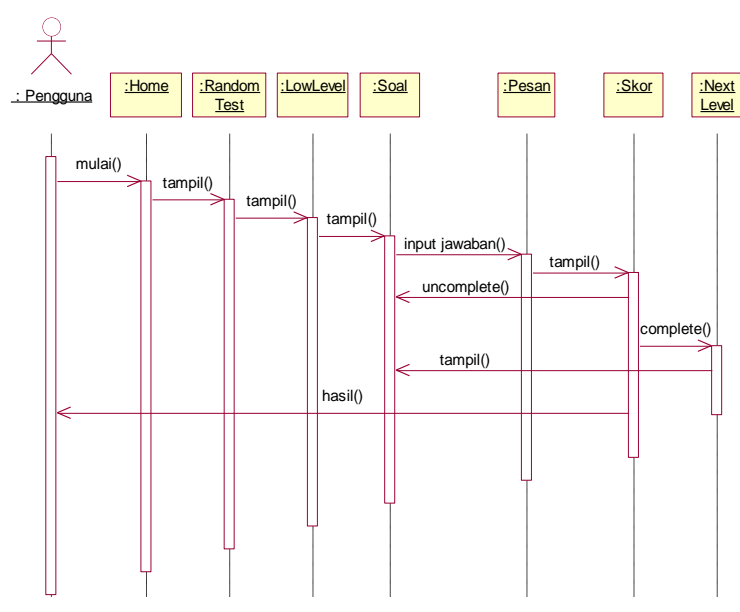

Gambar 5. Sequence Diagram 


\section{Rancangan Antarmuka Sistem}

Interface atau antarmuka adalah salah satu bagian dalam pembangunan sebuah aplikasi. Pada analisa dan perancangan ini, antar muka sistem yang ditampilkan adalah halaman utama.
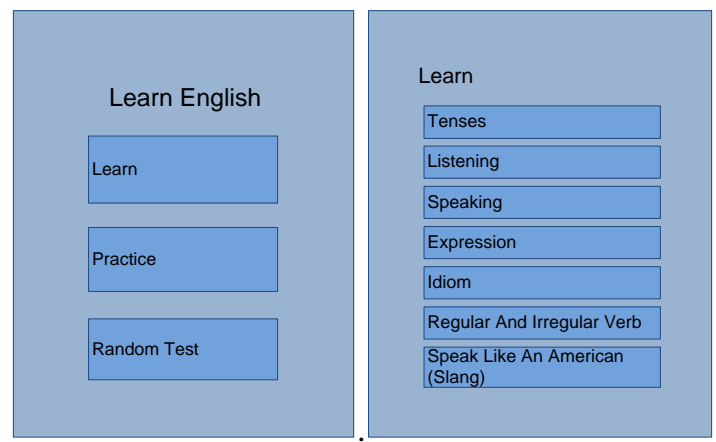

Gambar 6. Rancangan Antarmuka Sistem

\section{IMPLEMENTASI DAN PENGUJIAN}

\section{A. Hasil Implementasi}

Implementasi kali ini menggunakan perangkat dengan sistem operasi Android Versi 2.3 (Girngerbread). Hasil implementasi dapat dilihat pada gambar di bawah ini. Gambar dibawah ini adalah soal latihan tenses pada menu Tenses.

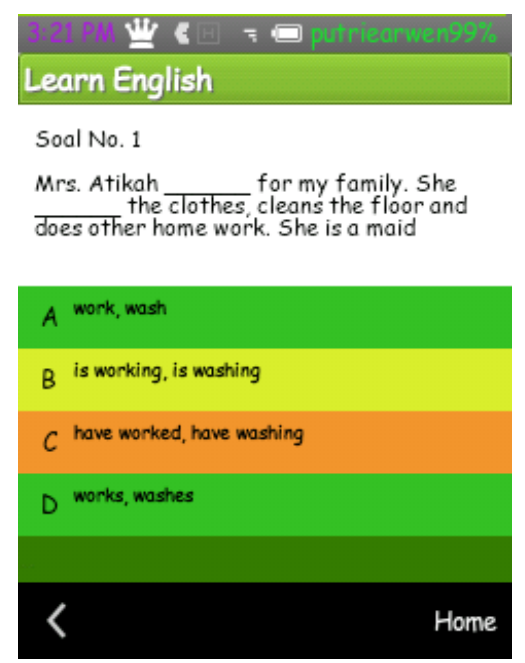

Gambar 7. Tampilan Halaman Practice Tenses

Pengguna harus memilih jawaban antara A, B, C, dan D. Jika jawaban yang dipilih benar maka akan tampil pesan berikut.

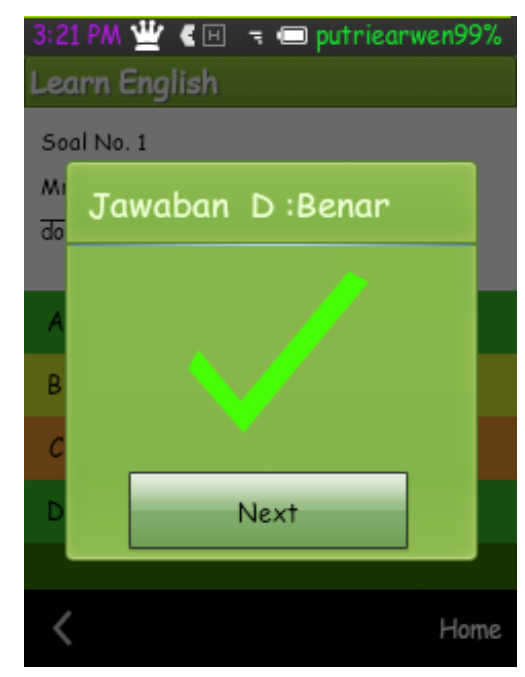

Gambar 8. Tampilan Pesan Jawaban Benar

Namun jika jawaban yang dipilih salah maka akan tampil pesan berikut.

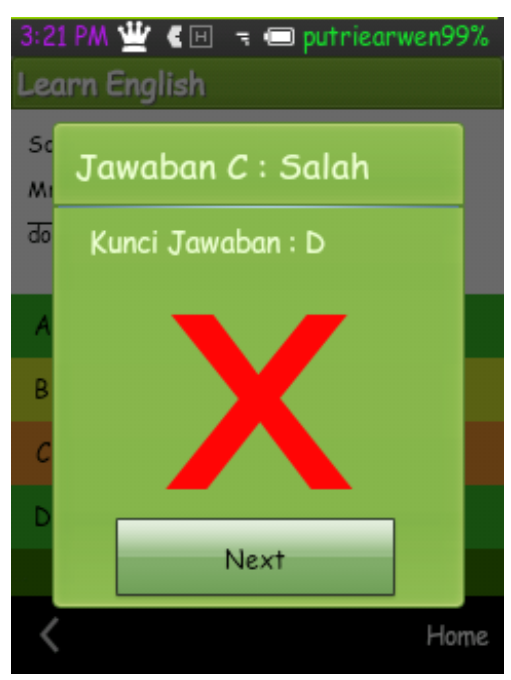

Gambar 9. Tampilan Pesan Jawaban Salah

Setelah pengguna selesai men-jawab sampai soal nomor 20, maka akan tampil perhitungan skor yang merupakan jumlah poin dari soal yang benar yaitu 5 poin. 


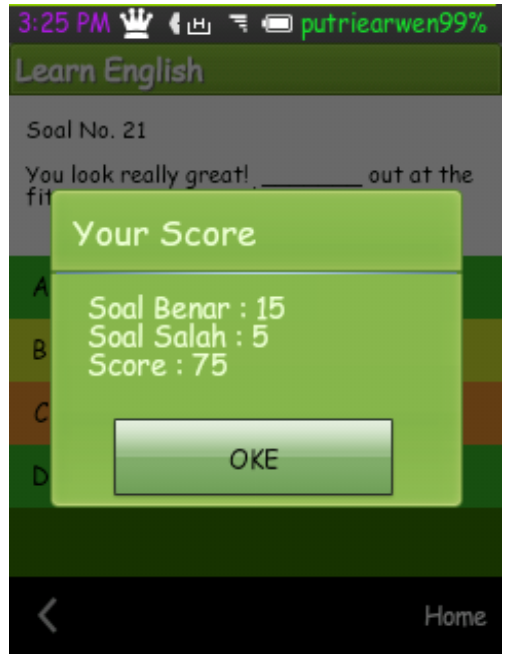

Gambar 10. Tampilan Skor

\section{B. Pengujian Kuesioner}

Untuk mengetahui penilaian dan tanggapan pengguna terhadap aplikasi pembelajaran bahasa Inggris, dilakukan ujicoba terbatas dan penyebaran kuesioner penilaian. Pengujian terbatas terhadap aplikasi ini dilakukan kepada siswa dan guru. Kategori pertanyaan kuesioner terbagi dua, yaitu aspek pembelajaran dan desain visual.

Nilai hasil kuesioner digolongkan dalam lima kategori dengan menggunakan skala sebagai berikut:

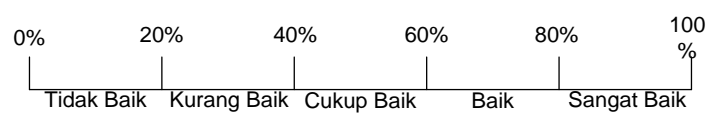

Gambar 11. Rating Scale

Tabel 11. Kategori Tingkat Rating Scale

\begin{tabular}{|l|l|}
\hline Presentasi & \multicolumn{1}{|c|}{ Interpretasi } \\
\hline $0 \%-19.99 \%$ & Tidak Baik \\
\hline $20 \%-39.99 \%$ & Kurang Baik \\
\hline $40 \%-59.99 \%$ & Cukup Baik \\
\hline $60 \%-79.99 \%$ & Baik \\
\hline $80 \%-100 \%$ & Sangat Baik \\
\hline
\end{tabular}

Rangkuman perhitungan hasil kuesioner siswa akan dibagi per aspek, yaitu aspek pembelajaran, aspek desain visual dan aspek secara keseluruhan. Dalam hal ini ditampilkan rating scale respon siswa dan guru dari aspek keseluruhan.

1. Aspek Keseluruhan Hasil Kuesioner Siswa Perhitungan kuesioer meng-hasilkan presentase $88 \%$, yang menandakan nilai responden secara keseluruhan terhadap aplikasi ini sangat baik.

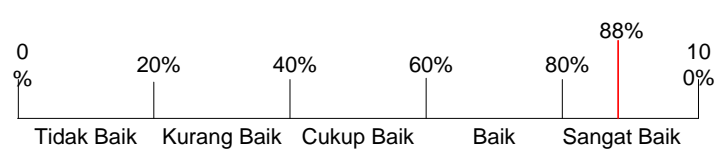

Gambar 12. Rating Scale Kuesioner Siswa dari Aspek Keseluruhan

2. Aspek Keseluruhan Hasil Kuesioner Guru

Perhitungan kuesioer meng-hasilkan presentase $85,7 \%$, yang menandakan nilai responden secara keseluruhan terhadap aplikasi ini sangat baik.

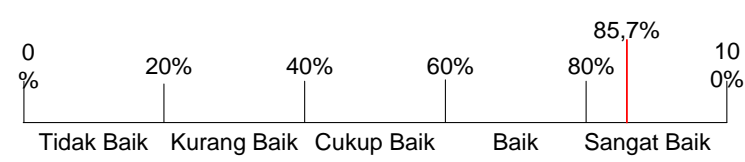

Gambar 13. Rating Scale Kuesioner Guru dari Aspek Keseluruhan

C. Kesimpulan Pengujian

1. Aplikasi yang dibangun sudah berjalan pada perangkat Android dan sukses menjalankan fungsi sebagai berikut:

a. Menampilkan materi pem-belajaran

b. Memutar audio yang sudah didownload dengan meng-gunakan tombol play, pause dan stop

c. Menentukan jawaban dari soal latihan yang diinputkan pengguna benar atau salah

d. Menggunakan teknologi Google Voice Search untuk menginputkan suara pada latihan Speaking

e. Menggunakan teknologi Text To Speech untuk menginputkan kata pada learn Speaking

f. Menghitung dan menampilkan skor setelah menjawab soal

g. Melakukan pencarian kata pada menu Idiom, Regular And Irregular Verb, dan Slang

h. Menjawab soal pada menu Random Test menurut tingkat kesulitannya

i. Update materi, update soal practice dan update soal Random Test dari server.

j. Berdasarkan hasil presentase kuesioner pengujian yang telah dilakukan perolehan nilai menunjukkan respon dari siswa dan guru secara keseluruhan terhadap aplikasi ini sangat baik.

\section{KESIMPULAN DAN SARAN}

Kesimpulan dari penelitian ini adalah:

1. Terwujudnya aplikasi mobile tentang pembelajaran bahasa Inggris pada platform 
Android sehingga pengguna dapat mengakses materi dimanapun dan kapanpun

2. Aplikasi pembelajaran bahasa Inggris yang dibangun dapat dijalankan dan berfungsi dengan baik sesuai analisa dan perancangan.

Beberapa hal yang disarankan dalam pengembangan aplikasi pembelajaran bahasa Inggris selanjutnya adalah sebagai berikut:

1. Aplikasi dapat berjalan pada multiplatform

2. Menyediakan login untuk input soal dan materi juga untuk pengguna

3. Pengembangan menjadi aplikasi jejaring sosial

\section{REFERENSI}

[1] Akhshabi, Mohammad dan Javad Khalatbari, Mostafa Akshabi. 2011. An Experiment On Conducting Mobile Learning Activities On The Virtual University. Islamic Azad University, Science and Research Branch, Department of computer Engineering,

[2] Ally, Mohamed. 2009. Mobile Learning Transforming the Delivery of Education and Training. [Online] Available http://www.aupress.ca/books/120155/ebook/99Z_ Mohamed_Ally_2009-MobileLearning.pdf, diakses tanggal 14 Maret 2013

[3] Amiral, Muhammad. 2010. Aplikasi Pengingat Sholat dan Arah Kiblat Menggunakan Global Positioning System (GPS) berbasis Android 1.6. Teknik Informatika, Institut Teknologi Indonesia.

[4] A. Suhendar. 2002. Visual Modeling Menggunakan UML dan Rational Rose. Informatika: Bandung

[5] Darwiyanti, Sri dan Romi Satria Wahono. Pengenalan Unified Modeling Language (UML) .[Online $\quad$ Available http://ilmukomputer.org/2006/08/05/pengantaruml/, diakses tanggal 15 Maret 2013

[6] Irmayanti, Ika Novrita. 2013. Rancang Bangun Aplikasi Jejaring Sosial Pembelajaran Matematika SMP Pada Platform Android. Laporan Tugas Akhir Sarjana, Jurusan Teknik Informatika, Universitas Islam Negeri Sultan Syarif Kasim Riau.

[7] Istiakharoh, Lutfi dan Saefurrohman. 2010. Peningkatan Kemampuan Listening Mahasiswa Dengan Mengunakan E-learning. Artikel Ilmiah Penelitian Dosen Muda. Fakultas Keguruan Dan Ilmu Pendidikan, Universitas Muhammadiyah Purwokerto.

[8] Meredith, Sandra dan Becci Newton. 2003. Models of eLearning: Technology Promise vs Learner Needs Literature Review. [Online] Avaiable http://www.heacademy.ac.uk/assets/document s/subjects/bmaf/Meredith_Models_of_elearni ng_lit_review.pdf, diakses tanggal 13 Maret 2013

[9] Thio Pratama Putra, Suwanto Sanjaya, Surya Agustian. 2012. Aplikasi Mobile Learning Berbasis Moodle Pada Platform Android. Konferensi Sistem Informasi (KNSI) STIKOM BALI. 541-546. ISBN 9786029876802.

[10] Quinn, C. Mobile Learning: Landscape and Trends. [Online] Available http://commons.lbl.gov/donload/attachments/7 7828943/mobile2011report-f2.pdf, diakses tanggal 13 Maret 2013

[11]Safaat, Nazruddin. 2011. Android: Pemrograman Aplikasi Mobile Smartphone dan Tablet PC Edisi Revisi. Informatika. Bandung.

[12] Simanjuntak, Herpinus. 2004. Bahasa Inggris Sistem 52M1 (Edisi Revisi). Kesaint Blanct. Jakarta.

[13] Simanjuntak, Herpinus. 2004. Bahasa Inggris Sistem 52M2 (Edisi Revisi). Kesaint Blanct. Jakarta.

[14] Simanjuntak, Herpinus. 2004. Bahasa Inggris Sistem 52M3 (Edisi Revisi). Kesaint Blanct. Jakarta.

[15] Sugiyono, 2013. Metode Penelitian Pendidikan Pendekatan Kuantitatif, Kualitatif dan $R \& D$. Alfabeta. Bandung.

[16] Wahono, RomiSatria. Pengantar e-Learning dan Pengembangannya. [Online] Available http://www.hadspartnership.net/dwld/11221676 82romi-elearning2.pdf, diakses tanggal 14 Maret 2013

[17] Wijaya, Kun Permadi. 2007. Perancangan Program Aplikasi Pembentukan Pola Fraktal Dengan Generator Iteration (Studi Kasus: Hade Lestari). Teknik Informatika, Universitas Bina Nusantara. 